\title{
CACTUS PRICKLY PEARS EXTRACT FOR COAGULATION/FLOCCULATION PROCESSES TO AMELIORE THE TREATEMENT OF OLIVE MILL WASTE WATERS MILL OLIVE (OMWW)
}

\author{
M.Neffa \\ H.Hanine \\ M. Taouir \\ Ait Yacine \\ Lekhlif B \\ University of Sultan Moulay Slimane, Faculty of Sciences and Technic, \\ Beni Mellal, Morroco.
}

\begin{abstract}
The oil industry, including olive oil, is one of the industries of food most pollutants, posing a serious environmental problem. In Morocco crushing units pouring the olive oil in their raw state without any prior treatment in the natural environment. These olive mill waste waters are characterized by low biodegradability because of phytotoxic and antibacterial substances (phenols, volatile fatty acids, insecticides...). They contain. This explains the persistence of pollution inherent in the (OMWW) observed over very long distances when they are discharged directly into rivers. Many techniques have been used to eliminate releases of (OMWW). These techniques, such as chemical or biological, are used individually or in combination. These techniques have shown the extent of their performance but also their limitations. This study aims to establish a process to use a novel flocculant and coagulant "Extract of cladodes from cactus "prickly pears" with clay in the coagulation-flocculation treatment. Among the expected subjects of this study: the performance evaluation process of purification and recovery of sludge from olive oil. For the coagulation-flocculation various tests will be conducted with one hand, the conventional coagulants $(\mathrm{Ca} 2+, \mathrm{Fe} 3+$ and $\mathrm{Al} 3+)$ and, on the other hand, alginate, extract of cactus prickly pears, and other flocculants style peel pomegranate. The parameters to be monitored are COD, BOD5, conductivity, $\mathrm{pH}$ and total polyphenolic. Their coagulation and flocculation properties can be used to remove particulate inorganic or organic suspensions, and also dissolved organic substances as the polyphenolic compounds. This study gives an overview of the main results obtained in the treatment of various suspensions and solutions.
\end{abstract}

\section{KEYWORDS}

Olive mill wastewater; treatment; biological processes; electro-coagulation; coagulation; prikly pears

\section{INTRODUCTION}

A major environmental concern in the Mediterranean countries is the disposal and/or treatment of the large quantities of olive mill wastewater (OMWW) produced during the olive-growing partner. In the Mediterranean area, where more than 95\% of the world's olives are harvested, up to 30 million tons of residues arise per year [1, 2, 3]. The high-

https://doi.org/10.15626/Eco-Tech.2010.024 
polluting power of OMWW is generally associated with the high chemical oxygen demand COD and biochemical oxygen demand BOD. Their concentrations were generally in the range 80-200 g 1/1 for COD [4] and 12-63 g 1/1 [5] for BOD. Specifically, it has been reported that polyphenolic components of OMWW are responsible for its antibacterial $[6,7$, $8]$ and phytotoxicity activity $[9,10]$.

The treatment of OMW has been the object of several studies. Many processes have been developed to treat this effluent: physico-chemical methods (flocculation, coagulation, filtration...), chemical oxidation using photocatalytic oxidation [11], wet oxidation [12] or advanced oxidation processes (AOP) [13] based on the generation of hydroxyl radicals (i.e. free radicals, Fenton's reagent, photocatalysis, a combination of ozone with hydrogen peroxide or UV radiation), electrochemical treatments, ultrafiltration/reverse osmosis, Biological methods used for OMWW treatment are aerobic activated sludge and anaerobic digestion. The interest in the electrochemical methods for the wastewater treatment, such as electro-coagulation (EC) and electrochemical separation, is permanently increasing [14]. It is based on the fact that the stability of colloids, suspensions and emulsions is influenced by electric charges. Therefore, if additional electric charges are supplied to the charged particles via appropriate electrodes, the surface charge of the particles is neutralized and several particles combine into larger and separable agglomerates [15].

In this study, the combined pre-treatment of actual olive mill wastewaters by electrocoagulation and coagulation with natural organic coagulant, such as extract from prikly pears, and the biological purification, was investigated. The removal efficiency of the treatment was determined by monitoring the decrease of COD, Total suspended solid (TSS), $\mathrm{pH}$, turbidity.

\section{MATERIALS AND METHODS}

\subsection{OMW and cactus used}

The original wastewaters used in the present study were obtained from an olive oil production plant located in the city of Beni Mellal in central Morocco, which uses was stored in a closed plastic container at ambient temperature (inhibitory activity of phenolic and fatty acids [16]).

The prickly pears ( cactus) juice obtained is relatively stable. It may retain its capacity flocculent outside any system of conservation for several days. This product is a viscous green color, $\mathrm{pH}=6.5$, water miscible, density $1008 \mathrm{~kg} / \mathrm{s}$ and contains about $96 \%$ water. Its analysis by UV spectroscopy gave the following spectrum (Figure. 1). 


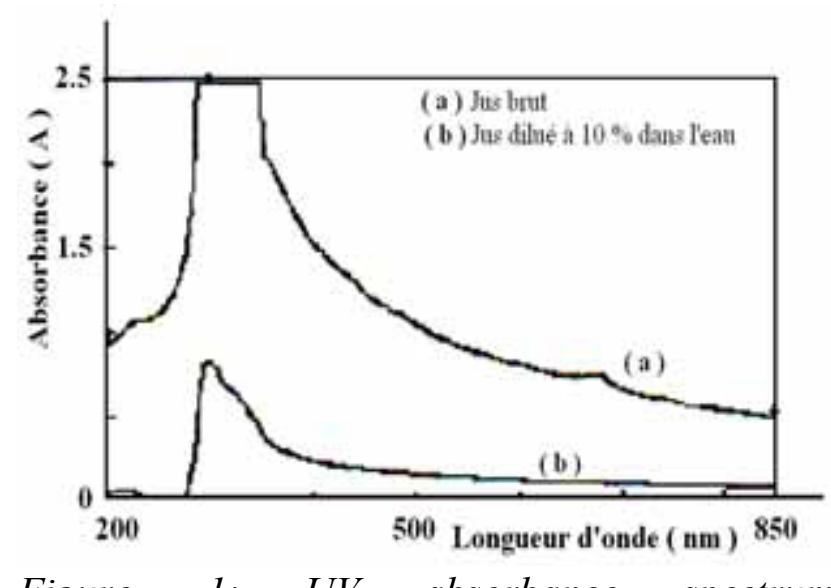

Figure. 1: UV absorbance spectrum of cactus juice to $300 \mathrm{~nm}$.

(A) Raw juice, (b) 30\% juice diluted in water

\subsection{Physical-chemical analysis of OMW}

A digital calibrated pH-meter (JENCO 6230) and a conductivity-meter (ORION 125) were used to measure the $\mathrm{pH}$ and the conductivity of the OMW wastewater samples. Total and dissolved chemical oxygen demand (COD) was determined by spectrophotometer method [17]. A spectrophotometer (UV-vis PALINTEST 7000) was used for the photometric COD. The turbidity was measured with a turbidimeter (ORBECO-HELLIGE).

Total suspended solid (TSS) was determined after filtering a sample through a GF/C filter $(0.45 \mu \mathrm{m})$ and drying the retained residue at $105^{\circ} \mathrm{C}$ for $4 \mathrm{~h}[18]$.

\subsection{Description of the process}

The treatment of polluted water by physico-chemical process, coagulation -flocculation has been achieved using a Jar-test (ISCO Model RPM / PMS) according to two main steps:

$\mathrm{PH}$ adjustment and coagulation. To adjust the $\mathrm{pH}$ of the solution, we used lime. This latter generally contributes to coagulation [8]. In parallel, the $\mathrm{CaCl} 2$ was used as a coagulant in some trials. This step occurs in a rapid stirring of $100 \mathrm{rpm}$ for one minute.- Flocculation. After adjusting the $\mathrm{pH}$ of coagulation - flocculation and to accelerate settling of suspended matter, we added the cactus juice as flocculant to promote the formation of macro flocs. The addition of flocculant is stirring at $80 \mathrm{rpm}$ for 30 seconds followed of slow stirring of $40 \mathrm{rpm}$ and decanting for 30 minutes.

- Electrocoagulation experiments were carried out using two parallel aluminum electrodes (STE 4,5 $\mathrm{cm}^{2} \times 2$ face) The anode/cathode gap was kept constant at $2 \mathrm{~cm}$. For each run, $100 \mathrm{~cm}^{3}$ of different dilution of OMWW were placed into the electrolytic cell. A gentle magnetic stirring rate of about $200 \mathrm{rpm}$ was applied to the electrolyte in all tests to allow the chemical precipitate to grow large enough for removal (with a stir bar of $\varnothing 6 \mathrm{~mm} \times 15 \mathrm{~mm}$ long). The voltage $(15 \mathrm{~V})$ was kept constant for each run. Thereafter, the samples were decanted for $24 \mathrm{~h}$ before being subjected to vacuum filtration through filters with a pore size of $0.45 \mu \mathrm{m}$. In the sample filtrated: COD, Total suspended solid (TSS), $\mathrm{pH}$, turbidity were measured. The total time duration of electrolysis was $180 \mathrm{~min}$ for most test runs. [STE effective area of electrode]

- Aerobic biofiltration system with plastic packing

Erlenmeyer flasks of 1L were used as flask reactors. $60 \mathrm{~mL}$ of OMWW diluted at $50 \% \mathrm{pH}$ neuter were tested. The inoculums used in the flask reactors was $20 \mathrm{~mL}$ sand filter 
and a rippled plastic hollow tube her tested as the support material of this reactor. Aquarium pumps were used to provide aeration. This particular support material was chosen, since it is commercially easy to find. The evolution of $\mathrm{pH}$ and soluble COD was analyzed after 19 day.

Fungal remediation of OMWW has been studied using fungi (X). Two different OMWW were tested: OMWW diluted at 50\% pH acid, OMWW diluted at 50\% pH neuter adjusted by adding lime coagulant and OMWW pretreatment bay both coagulants (lime and Kim 2120). The evolution of $\mathrm{pH}$ and soluble COD was analyzed every day.

\section{RESULTS AND DISCUSSION}

\subsection{Treatment by coagulation-flocculation}

Preliminary tests were performed to assess the relative efficiency of various coagulants to destabilize OMW at different dilution.

The composition of the OMWW used is reported in the table 1 which shows the difference between two raw materials OMWW_from two different triturating processes.

Table 1.Physico-chemical characteristics of fresh and diluted olive mill wastewaters with tap water used (Traditionnal and Moderne)

\begin{tabular}{|l|c|c|}
\cline { 2 - 3 } \multicolumn{1}{c|}{} & Traditionnal & $\begin{array}{c}\text { Tree phase } \\
\text { extraction }\end{array}$ \\
\hline $\mathrm{pH}$ & 5,34 & 4,82 \\
\hline conductivity en (ms/cm) & 16,9 & 15,3 \\
\hline Turbidity NTU & 121 & 101 \\
\hline MS (g/l) & 112 & 108 \\
\hline COD (g O /1) & 155 & 165 \\
\hline POLYPHENOLIC g/1 & 5,47 & 6,66 \\
\hline Sugar g/1 & 33,56 & 17,1 \\
\hline DO 395 nm & 7,32 & 7,05 \\
\hline DO 280 nm & 52,91 & 40,88 \\
\hline
\end{tabular}




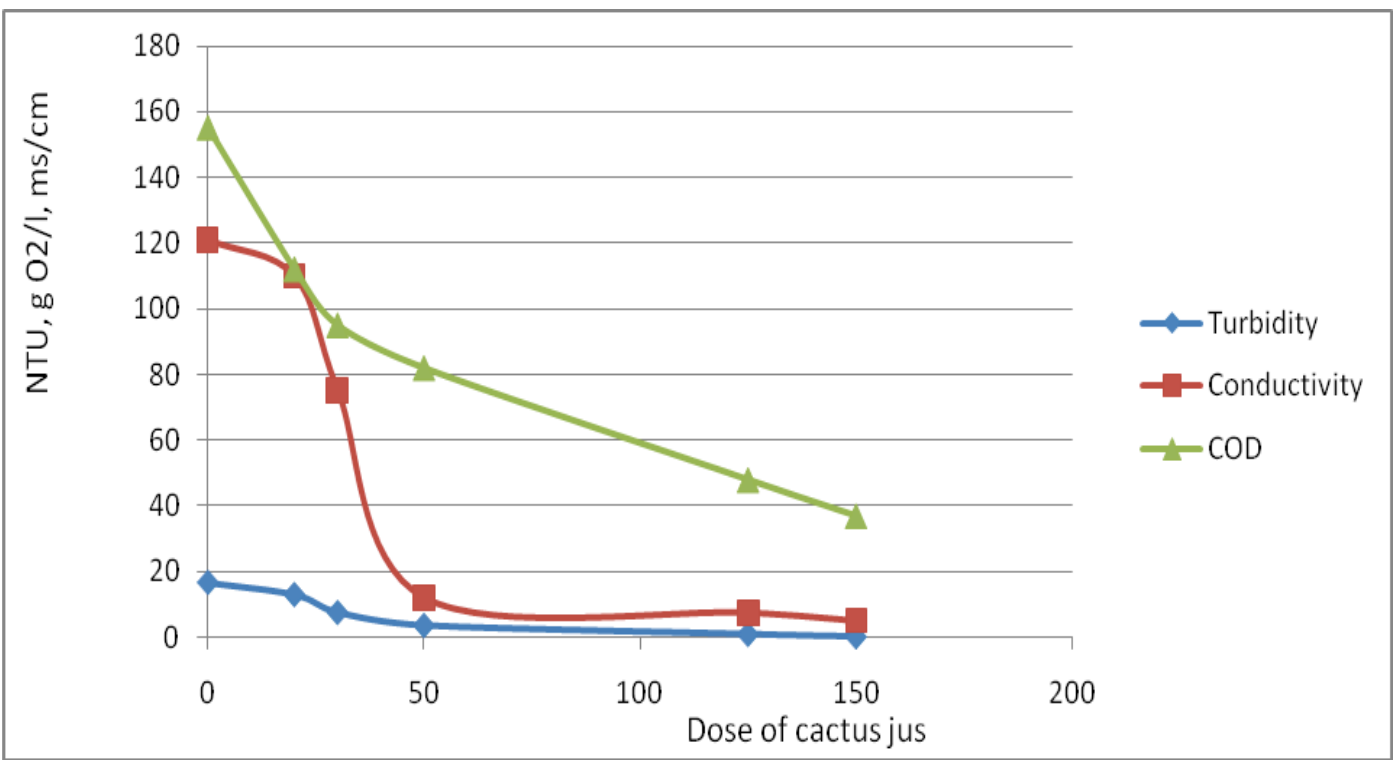

Figure.2: The effect of differente dose of cactus jus on the efficience of treatment of OMWW diluted to $60 \%$

The effect of various dose of cactus juice showed a marked improvement of the tretabilité OMWW. A respective decrease of $75 \%$ of COD is achieved, $90 \%$ for suspended solids (conductivity) with an optimal dose of $150 \mathrm{ml} / 1$ of OMWW.

\subsubsection{Optimization of OMWW pre-treatment by coupling lime and extract of prikly pears $(150 \mathrm{ml} / \mathrm{l})$}

The addition of different volumes of lime that allows a $\mathrm{pH}$ increase to 7, OMWW are coagulated and at the same time diluted. Figure 3 . shows the changes on the removal of COD and turbidity measured in the treated OMWW according to the lime concentrations. 


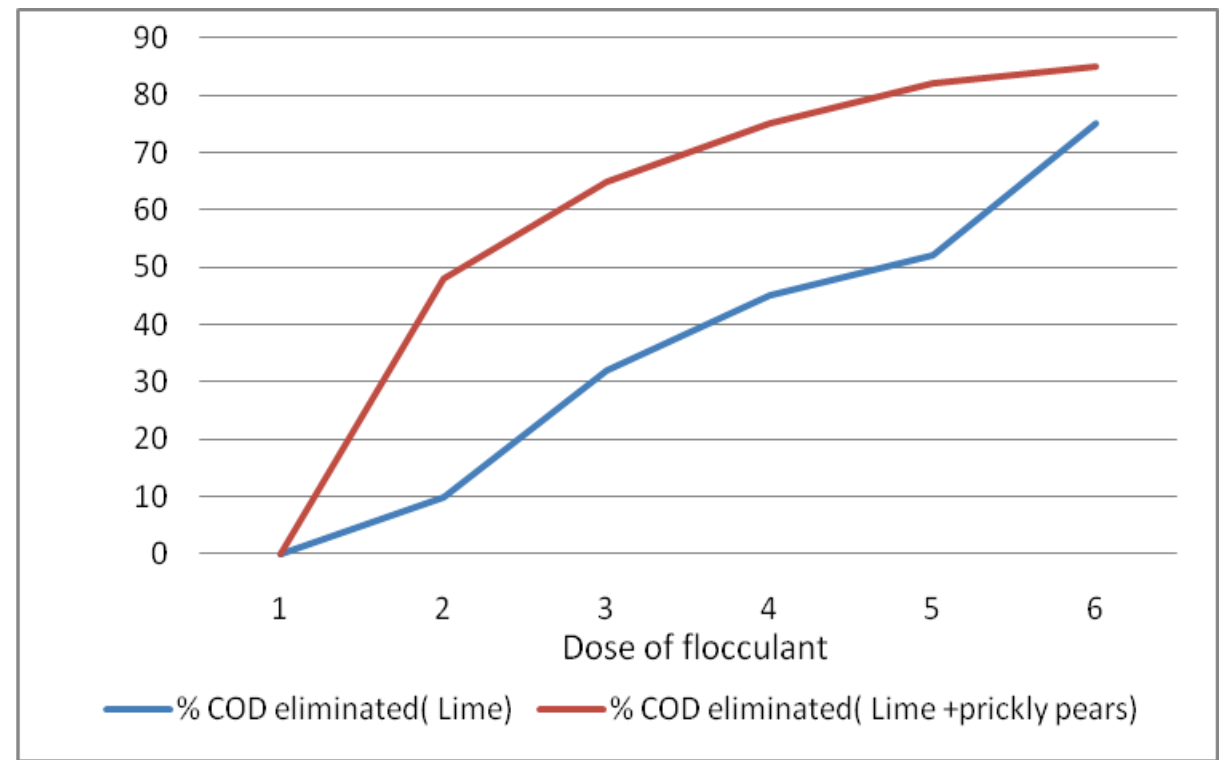

Figure.3. The change of the pourcebtage of COD eliminated according to the dose of the flocculant

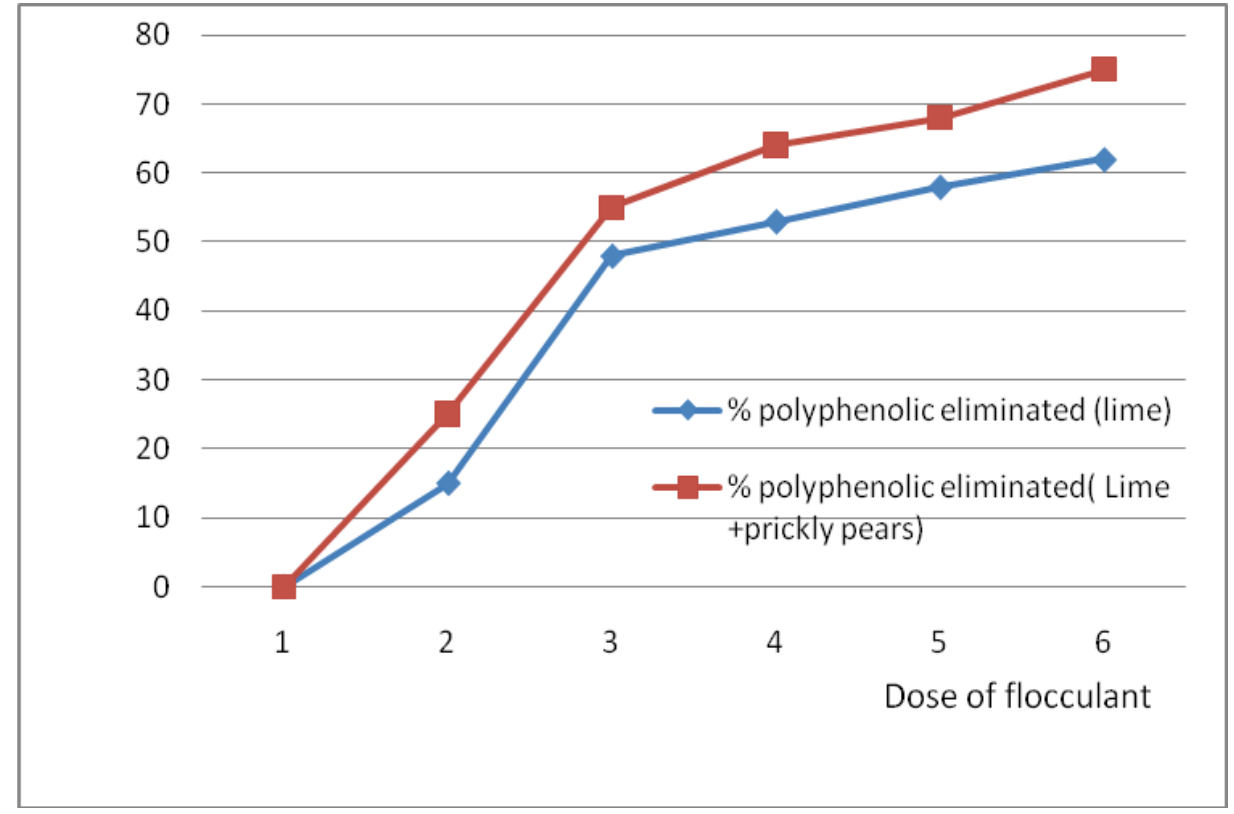

Figure.4. The change of the pourcebtage of polyphenolic compounds eliminated according to the dose of the flocculant

This result shows that lime combined to $150 \mathrm{ml}$ of pearky pears extract per litre of OMMW has a very important removing capacity of the polluting matters by coagulation. In this regard, Khoufi et al., 2007 [21] and Esra Aktas et al. (2000) [22] have attributed the lime effect in the OOWW pre-treatment to the polymerization and precipitation of long chain fatty acids and on a large molecular mass polyphenols. 


\subsection{Integrated coagulants and biological treatment of OMWW}

Coupling different coagulants and biological processes has received a lot of attention in recent years as a promising treatment alternative for effluents that are too toxic to treat biologically. The aim of the coagulation step was to remove TSS in order to improve the efficiency of the subsequent treatment by biological treatment. Accordingly coagulation efficiency was investigated in terms of COD removal, $\mathrm{pH}$ and Tyrosol, Hydroxytyrosol phenols. Two studies have compared the effectiveness of two different types of coagulants for the bioremediation of OMWW.

\subsubsection{Aerobic treatment of OMWW with a sand filter and a rippled plastic}

The results in Fig. show the evolution of removal COD during 19 days after aerobic treatment of OMWW with a sand filter, the removal efficiencies of COD in the aerobic filters plastic were about $63 \%$. Such high performance strongly suggests that sand filter bacteria are capable of degrading the phenol and COD of OMWW ( figure.5).

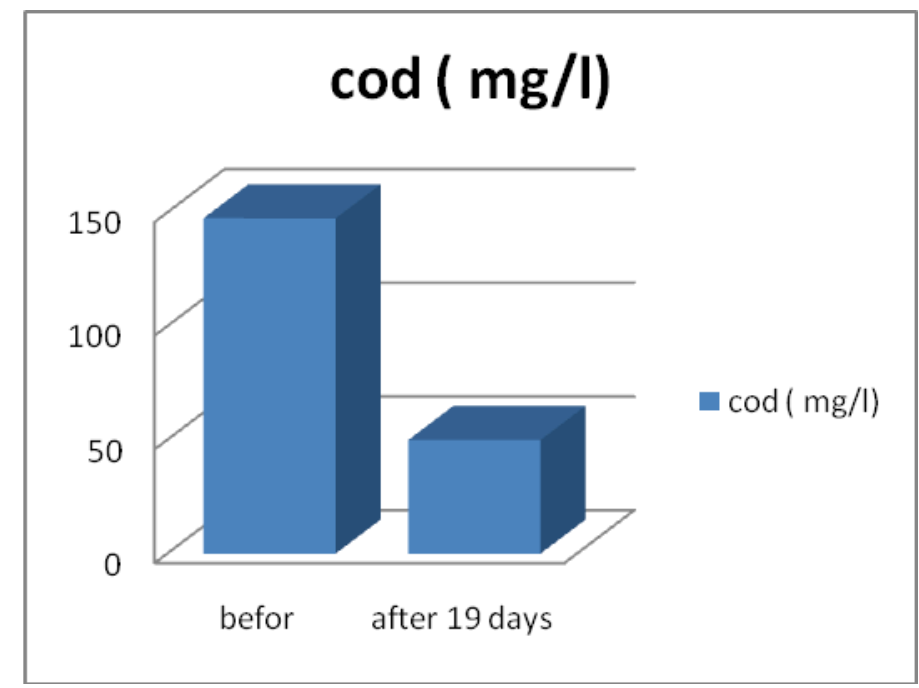

Figure.5.The variation in COD removal in the aerobic treatment with coagulant pre-treated $O M W W$.

\subsubsection{Fungal remediation of OMWW}

The COD and $\mathrm{pH}$ changes in OMWW after incubation in the assays inoculated with Fungi cultivated on diluted OOMW at $60 \%$ and diluted OMWW at $50 \%$ treated by lime and lime/, Results indicate that removed respectively $68 \%$ and $75 \%$ of the COD after 5 days cultivation ( table .4). Pretreatment by lime and lime/extract from peakly pears reduces the toxicity of OMWW and improved its biodegradability since the removal of COD was more important than obtained with unmodified OMWW. Possibly this could result from a toxic effect of the OMWW phenolic and/or other compounds, when present above a critical concentration.

The results of this work are relatively similar to those found by previous workers. Hamdi et al. (1991) [29] obtained a 52.5\% removed COD using A. niger in aerobic condition. Borja et al. (1995) [30], found COD and phenols reductions of $63.3 \%$ and $65.6 \%$ respectively by using G. candidum[32], . 
The $\mathrm{pH}$ of the fermented OMWW was always much higher than their initial values. The observed $\mathrm{pH}$ increase was due to the consumption of organic acids such as lactic and acetic acids present in the OMWW [31], 1983 or also through release of $\mathrm{NH}_{4}{ }^{+}$after degradation of proteins. The results of $\mathrm{pH}$ showed that the best aerobic treatment can be obtained with Neutral $\mathrm{Ph}$ and under this conditions we obtained the result from figure .6.

Table 4. The efficience of the treatment used, coupled with Lime and biological treatment

\begin{tabular}{|l|l|l|}
\hline OMWW & COD Eliminated \% & $\begin{array}{l}\text { Phenolic compounds } \\
\text { eliminated \% }\end{array}$ \\
\hline OMWW (1)treated with lime & 72 & 17.15 \\
\hline $\begin{array}{l}\text { OMWW(2) treated with } \\
\text { lime+jus of prickly pears }\end{array}$ & 82 & 72 \\
\hline $\begin{array}{l}\text { OMWW(2)+ biological } \\
\text { treatment }\end{array}$ & 92 & 85 \\
\hline
\end{tabular}

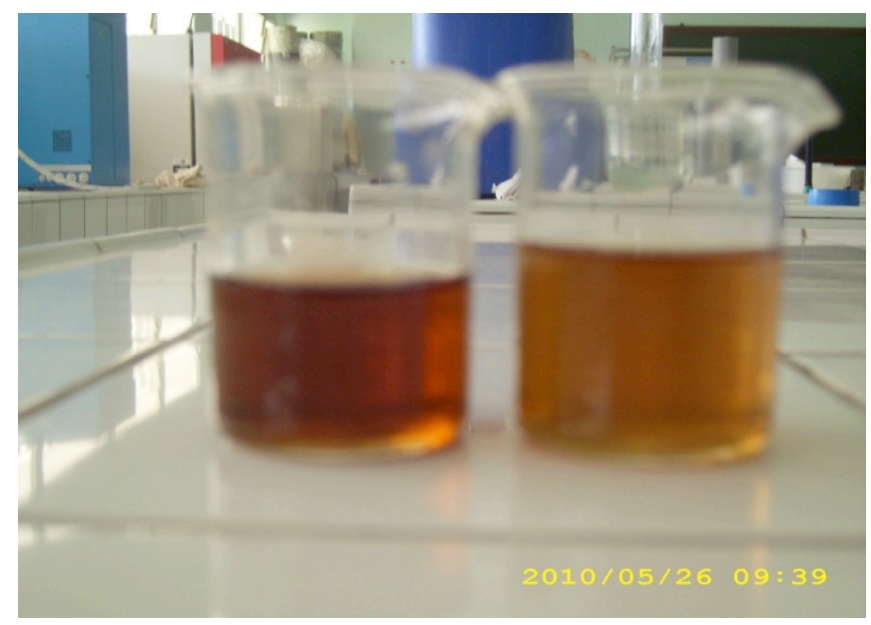

Figure 6.

\section{CONCLUSION}

The cactus tree is native of the arid and semi-arid areas in Mexico. It belongsto the genus Opuntia ficus Indica, a succulent plant xérophytique which can store a large amount ofwater and doesn't affect the human health .Furthermore, it presents considerable values in different domaines such as cosmetics, medecine and food. The main aimof this study is to use a new biodegradable flocculent with a Moroccan cactus juice in a physico -chemical process (flocculation coagulation) in order to treat liquid solutions OMWW charged with polyphenolic compounds, , higher colorant and suspended matter. We also study the efficacy of this juice associated with a lime.

The coagulation one combined with lime, followed by a flocculation then a decanting operation, has showed a significant effect on the elimination of polyphenolic compounds and COD that may exceed 85 and $92 \%$. 


\section{REFERENCES}

[1] Fountoulakis M.S, Dokianakis.S.N, Kornaros.M.E, Aggelis.G.G, Lyberatos.G, 2002, Removal of Phenolic in Olive Mill Wastewaters Using The Whiterot Fungus Pleurotus Ostreatus, Water Res. 36,4735-4744.

[2] Sabbah.I, Marsook.T, S. Basheer, 2004, The Effect of Pretreatment on Anaerobic Activity of Olive Mill Wastewater Using Batch and Continuous Systems, Process Biochem. 39, 19471951.

[3]Caputo.A.C, Scacchia.F, Pelagagge.P.M, 2003, Disposal of By-products in Olive Oil Industry: Waste-to-Energy Solutions, Appl. Therm. Eng. 23 , 197-214.

[4] Scioli.C, Vollaro.L, 1997, Use of Yarrowia Liplytica to Reduce Pollution in Olive Mill Wastewaters, Water Res. $31,2520-2524$.

[5]Cossu.R, Balakey.N, Cannas.P, 1993, Influence of Codisposal of Municipal Solid Waste and Olive Vegetation Water on The Anaerobic Digestion of Sanitary Landfill, Water Sci. Technol. 27, 261-271.

[6] Casa.R, D’Annibale.A, Pieruccetti.F, Sazi.S.R, G. Giovanorozzi Sermani.G, Cascio.B LO, 2003, Reduction of The Phenolic Components in Olive-Mill Wastewaters by an Enzymatic Treatment and Its Impact on Durum Wheat (Triticum Durum Desf.) Germinability, Chemosphere, 50 959-966

[7]Capasso.R, Evidente.A， Schivo.L， Gorru.G， Marcialis.M.A， Cristinzio.G, 1995, Antibacterial Polyphenols From Olive Oil Mill Waste Waters, J. Appl. Bacteriol. 79, 393398.

[8]Borja.R, Alaj, Mancha.A, Martin.A, Alonso.V, Sanchez.E, 1998, Comparative Effect of Different Aerobic Pre-Ttreatments on The Kinetics and Macroenergetic Parameters of Anaerobic Digestion of Olive Mill Waste Water in Continuous Mode, Bioproc. Eng. 18 , 127-134.

[9] Capasso.R, Cristinzio.G, Evidente.A, F. Scogniamiglio.F, 1991, Isolation, Spectroscopy and Selective Phytotoxic Effects of Polyphenols From Vegetable Wastewaters, Phytochemistry , 31, 4125-4128.

[10] Aliotta.G, Cafiero.G, De Feo.V, Di Blasio.B, Iacovino.R, Oliva.A, 2000, Allelomichals From Rue (Ruta Graveolens L.) and Olive (Olea Europea L.) Oil Mill Waste as Potential Natural Pesticides, Curr. Top. Phytochem. 3, 167-177.

[11] Badawy.M.I, Gohary.F.EL, Ghaly.M.Y, M.E.M. Ali, 2009, Enhancement of Olive Mill Wastewater Biodegredation by Homogeneous and Heterogeneous Photocatalytic Oxidation, J. Hazard. Ma Ter. 169 1-3, 673-679.

[12] Minh.D.P, Gallezot.P, Azabou.S, Sayadi.S, Besson.M, 2008, Catalytic Wet Air Oxidation of Olive Oil Mill Effluents. 4. Treatment and Detoxification of Real Effluents, Appl. Catal. B: Environ. 84 (3-4) , 749-757.

[13] Canizares.P, Lobatoa.J, Paz.R, Rodrigo.M.A, Saez.C, 2007,Advanced Oxidation Processes for The Treatment of Olive-Oil Mills Wastewater, Chemosphere 67, (4) ,832-838.

[14] Pouet.M.F, Persin.F, Rumean.M, 1992, Intensive Treatment by Electro-CoagulationFlotation Tangential Flow Microfiltration in Areas of High Seasonal Population, Water Sci. Technol. $25,247$.

[15] Koparal.A.S, Bakir O Gutveren.U, 2002, Removal of Nitrate From Water by Electroreduction and Electrocoagulation, J. Hazard. Mater. B89 , 83-94.

[16] Gonzales.M.D, Moreno.E, Quevedo-Sarmiento.J, Ramos-Cormezana.A, 1990, Studies on Antibacterial Activity of Waste Waters From Olive Oil Mills (Alpechin): Inhibitory Activity of Phenolic and Fatty Acids, Chemosphere 20, 423-432

[17] Apha, 1992. American Public Health Association Standard Methods for Analysis of Waste and Waste Water. Apha, Pub., Washington DC. 
[18] Afnor (1983). Recueil de Normes Francaise : Eau, Methodes D’Essai, 2e Édition, Paris, France, $621 \mathrm{P}$.

[19] Kobya.M, Can.O.T, Bayramoglu.M, 2003, Treatment of Textile Wastewaters by Electrocoagulation Using Iron and Aluminum Electrodes, J. Hazard. Mater. $100,163-178$.

[20]Mollah.M.Y.A, Morkovsky.P, Gomes.J.A.G, Kesmez.M, Parga.J, Cocke.D.L, 2004, Fundamentals, Presnet and Future Perspectives of Electrocoagulation, J. Hazard. Mater. 114 ,199-210.

[21] Khoufi.S, Feki.F, Sayadi.S, 2007, Detoxification of Olive Mill Wastewater by Electrocoagulation and Sedimentation Processes, Journal of Hazardous Materials, 142 , 58-67. [22] Esra. S. Et AL., 2000. Characterization and Lime Treatment of Olive Mill Wastewater. Technical Note, 35, 9, 2336-2340.

[23] Hanafi.F, Assobeih.O, Mountadar.M, 2010, Detoxification and Discoloration of Moroccan Olive Mill Wastewater by Electrocoagulation, Journal of Hazardous Materials, $174,807-812$.

[24] Vik.E.A, Carlson.D.A, Eikuma.S, Gjessing.E.T, 1984, Electrocoagulation of Potable Water, Water Res. 18, 1355-1360.

[25] Chen.G.H, Chen.X.M, Yue.P.L, 2000, Electrocoagulation and Electroflotation of Restaurant Wastewater, J. Environ. Eng. ASCE 126, 858-863.

[26] Khoufi S., Et Al., 2007, Detoxification of Olive Mill Wastewater by Electrocoagulation and Sedimentation Processes Journal of Hazardous Materials, 142 , 58-67

[27] Tir.M, Moulai-Mostefa.N, 2008, Optimization of Oil Removal From Oily Wastewater by Electrocoagulation Using Response Surface Method, Journal of Hazardous Materials , 158 ,107-115

[28] Mouedhen.G, Feki.M, De Petris Wery.M, Ayedi.H.F, 2008, Behavior of Aluminum Electrodes in Electrocoagulation Process, Journal of Hazardous Materials ,150 , 124-135

[29] Hamdi. M, Garcia J.L. 1991, Comparison Between Anaerobic Filter and Anaerobic Contact Process for Fermented Olive Mill Wastewaters. Biores. Technol, 38, 23-29.

[30] Borja.R., Martin.A., Alonso.V., Garcia.I., Banks.C.J., 1995. Influence of Different Aerobic Pretreatments on The Kinetics of Anaerobic Digestion of Olive Mill Wastewater. Water Research 19, 489-495.

[31] Ercoli.E, Ertola .R, 1983 SCP Production From Olive Black Water. Biotechnol. Lett, 7, 457-462.

[32] Hafidi.M, Ait Badi.G, Chetoui.A. 2004, Traitement des Effluents Liquids D'Huileries D'Olives Par Des Micro-Organismes Aerobies. Agrochimica, XLVIII (1-2):1-12. 